\title{
The European Commission Tax Package: The Condition of Foreseeable Relevance, Group Requests and Data Breaches
}

\section{The PACKAge}

On 15 July 2020, the European Commission presented a Tax Package ${ }^{1}$ with the purpose of supporting the EU economic recovery and long-term growth. It is composed of three initiatives that are considered to be related: a tax action plan for fair and simple taxation supporting recovery $^{2}$ for which digital solutions are being assessed in order to implement measures that are more efficient in the relationship between taxpayers and tax administrations; a proposal on administrative cooperation introducing automatic exchange of information for income accrued to sellers on digital platforms (DAC 7$)^{3}$; and a communication on tax good governance ${ }^{4}$ announcing the reform of the Code of Conduct, improvements to the EU list of non-cooperative jurisdictions, and a plan to work with developing countries in the area of taxation in accordance with the 2030 Sustainable Development Agenda.

The package favours procedural rules or, more precisely, instruments for the national tax administrations to implement their taxes. It adheres to the tax measures adopted in the European Union in the context of transparency and multilateral exchange of information (Directive 2001/16/ EU (Directive on Administrative Cooperation, DAC1) ${ }^{5}$ and subsequent DACs). It also complements the AntiTax Avoidance Directive ${ }^{6}$ and the fight against base erosion and profit shifting (BEPS 1.0) $)^{7}$ if the BEPS 1.0 measures are understood as instruments that grant mechanisms for national tax administrations to implement their own taxes. Additionally, in general, it is parallel to the OECD work. This is the case of DAC $7^{8}$ that aims to implement the OECD Model Rules for Reporting by Platform Operators with Respect to Sellers in the Sharing and Gig Economy (MRDP) in the European Union. ${ }^{9}$ According to both the MRDP and DAC 7, digital platforms are required to collect information on the income accrued to those offering accommodation, transport, and personal services through platforms and to report information to tax authorities. ${ }^{10}$

The package, if approved, is not a novelty or a rupture with previous work even if the purpose of addressing the fiscal crisis related to Coronavirus diseases 2019 (COVID-19) is invoked. It shows a trend on the type of measures that EU Member States have agreed upon in recent years, i.e. the reinforcement of implementation measures related to national taxes and stronger administrations in times of economic, financial, and fiscal crises.

The Commission's fair tax agenda is ambitious, nevertheless, in attempting to eliminate obstacles to harmonization and coordination by exploring the application of Article 116 of the TFEU to taxes, all with the purpose of achieving enough fiscal revenue and preventing profit shifting to non-cooperative jurisdictions.

COVID-19 may be an opportunity to strengthen the powers of tax administrations similar to what occurs with

\section{Notes}

European Commission, Fair and Simple Taxation: Commission Proposes New Package of Measures to Contribute to Europe's Recovery and Growth, Press release (15 July 2020), https:// ec.europa.eu/commission/presscorner/detail/en/ip_20_1334 (accessed 12 Aug. 2020).

2 European Commission, Communication from the Commission to the European Parliament and the Council, An Action Plan for Fair and Simple Taxation Supporting the Recovery Strategy, COM 2020312 final (15 July 2020), https://ec.europa.eu/taxation_customs/sites/taxation/files/2020_tax_package_tax_action_plan_en.pdf (accessed 12 Aug. 2020).

3 European Commission, Proposal for a Council Directive Amending Directive 2011/16/EU on Administrative Cooperation in the Field of Taxation, COM (2020) 314 final, (15 July 2020), https://ec.europa.eu/taxation_customs/sites/taxation/files/2020_tax_package_dac7_en.pdf (accessed 12 Aug. 2020).

4 European Commission, Communication from the Commission to the European Parliament and the Council on Tax Good Governance in the EU and Beyond, COM(2020) 313 final (15 July 2020), https://ec.europa.eu/taxation_customs/sites/taxation/files/2020_tax_package_tax_good_governance_communication_en.pdf (accessed 12 Aug. 2020).

5 Council Directive 2011/16/EU of 15 Feb. 2011 on administrative cooperation in the field of taxation and repealing Directive 77/7999/EEC, OJ L64/1, (11 Mar. 2011).

6 Council Directive (EU) 2016/1164 of 12 July 2016 laying down rules against tax avoidance practices that directly affect the functioning of the internal market, O L 193/1, (19 July 2016).

OECD, Action Plan on Base Erosion and Profit Shifting, (OECD Publishing 2013), https://www.oecd.org/ctp/BEPSActionPlan.pdf (accessed 12 Aug. 2020).

8 European Commission, supra n. 3 .

9 OECD, Model Rules for Reporting by Platform Operators with Respect to Sellers in the Sharing and Gig Economy, (OECD Publishing 2020), https://www.oecd.org/tax/exchange-oftax-information/model-rules-for-reporting-by-platform-operators-with-respect-to-sellers-in-the-sharing-and-gig-economy.htm, (accessed 12 Aug. 2020),

10 European Commission, supra n. 3 and OECD, supra n. 9. 
increasing powers of national governments. While data protection is a flag in the European Union - a fundamental right on its own - the increasing use of data by tax administrations, the data exchange, and the recommended joint processing of it using Eurofisc 2.0 as an EU hub for tax information should deserve better attention from the perspective of taxpayers' rights.

\section{The EU INTERNATIONAL STANDARD OF FORESEEABLE RELEVANCE}

Foreseeable relevance as a condition for a requested state to exchange information on income accrued in its territory and belonging to taxpayers resident in a requesting state has been included in several international instruments: Article 26 OECD Model Convention and explained in the 2005 Commentary, Article 1 of the 2002 OECD Model Agreement on Exchange of Information (TIEAs Model), the OECD/Council of Europe Multilateral Convention on Mutual Assistance, signed in 1988 and in force since 1 April 1995, as well as in the 2006 Manual on Implementation of Exchange of Information. ${ }^{11}$

This limit was related to exchange of information upon request and justified as a protection of taxpayers' data and (other) fundamental rights including the right to protection of reputation and good name as well as to a fair hearing and trial.

The EU Mutual Assistance Directive 2011/16/EU, 15 February 2011 (DAC 1), adopted on the basis of 113 and 115 TFEU, accords with the parallel trend with international standards and grants primacy to automatic exchange of information. Similar to the international instruments, its aim is to combat practices of tax evasion and tax avoidance as well as enable taxes on income and capital to be correctly assessed. DAC 1 also makes reference to foreseeable relevance in its Article 1, which is placed under Chapter I, General Provisions.

\section{Foreseeable Relevance AND the INTERNATIONAL STANDARD ON AUTOMATIC EXCHANGE OF INFORMATION}

Whereas foreseeable relevance in the international scenario has been related to exchange of information upon request, on 13 February 2014, the OECD released a Single Global
Standard for Automatic Exchange of Information between Competent Authorities (CAA). According to this new standard, jurisdictions obtain financial account information from their financial institutions and exchange this information automatically on an annual basis. The financial account information encompasses all types of investment income (interest, dividends, income from certain insurance contracts, and other similar types of income), account balances, and sales proceeds from financial assets. ${ }^{12}$

In respect of automatic exchange of information, the DAC goes much further than the international standard. Article 8 (1) DAC provides for automatic exchange of information in respect of:

1. income from employment;

2. director's fees;

3. life insurance products not covered by other Union legal instruments on exchange of information and other similar measures;

4. pensions;

5. ownership of and income from immovable property;

6. The DAC 7 Proposal adds 'royalties' to this list.

Furthermore, it is intended that Member States implement at least two of the categories of Article 8 enumerated above, and the DAC 7 Proposal foresees automatic exchange of information in at least four of those categories.

Since automatic exchange of information became the international standard, discussion on the legal limits to tax authorities accessing and exchanging taxpayers' data, including on the role played by 'foreseeable relevance', is obsolete to a great extent. Automatic exchange of information established the necessary mechanisms to overcome that limit through a massive and periodic flow of information from the source state to the state of residence of the taxpayer.

Automatic exchange of information is a much more powerful instrument for tax authorities in the context that the information exchanged is unconditional to taxpayers' data protection and any privacy rights. Automatic exchange of information presumes 'foreseeable relevance'.

Under the current international standard, transparency is the primary goal allegedly aimed at eliminating hidden wealth and associated uncooperative jurisdictions. In this context, recent developments on the interpretation of foreseeable relevance illustrate that it is often related to

\section{Notes}

11 See A. P. Dourado, Article 26: Exchange of Information, in Klaus Vogel on Double Taxation Conventions, 20-23 (E. Reimer \& A. Rust eds, Wolters Kluwer 2015); A. P. Dourado, The EC Draft Directive on Interest from Savings from a Perspective of International Tax Law, 9(3) EC Tax Rev. 144 (2000); A. P. Dourado, Exchange of Information and Validity of Global Standards in Tax Law: Abstractionism and Expressionism or Where the Truth Lies, 11 EUI Working Paper RSCAS (2013); A. P. Dourado, Fake Tax Transparency? Leaks and Taxpayer Rights, 46(2) Intertax 100 (2018); A. P. Dourado, The EU Black List of Third-Country Jurisdictions, 46(3) Intertax 178 (2018); A. P. Dourado, Whistle-Blowers in Tax Matters: Not Public Enemies, 46(5) Intertax 422 (2018); K.-D. Drüen, Implementation of Provisions of Mutual Assistance in Tax Affairs, in Mutual Assistance and Information Exchange EATLP International Tax Series vol. 8, 55 (R. Seer \& I. Gabert eds, IBFD 2010); K.-D. Drüen, Chapter 4: The Mutual Assistance Directives, in Exchange of Information and Bank Secrecy 77 (A. Rust \& E. Fort eds, Wolters Kluwer 2012); S. Eilers, Article 26 in Doppelbesteuerung (F. Wassermeyer ed., Beck 2012); New Exchange of Information Versus Tax Solutions of Equivalent Effect, EATLP International Tax Series Vol. 13, (G. Marino ed., IBFD 2016); R. Seer, Recent Developments in Exchange of Information within the EU for Tax Matters, 22(2) EC Tax Rev. 66 (2013); R. Seer, \& I. Gabert, General Report, in Mutual Assistance and Information Exchange EATLP International Tax Series vol. 8 , 23 (R. Seer \& I. Gabert eds, IBFD 2010).

12 Dourado, Article 26: Exchange of Information, supra n. 11, at 7-19. 
the protection of the requested tax administration and allocation of its resources in the benefit of the other state rather than the protection of the taxpayer's rights. ${ }^{13}$

\section{ForeseEABLE RELEVANCE AND DAC 7}

Therefore, to a certain extent, it is surprising that the proposal for a DAC 7 defines foreseeable relevance. Additionally, although foreseeable relevance was neither defined in the international instruments nor in the Mutual Assistance Directive (DAC), the commentaries to the OECD Model Convention, the OECD Manual on Mutual Assistance, and the commentaries to the Tax Information Exchange Model Convention allowed understanding its meaning and applying it to the DAC.

The clear limits were fishing expeditions defined in the Manual on Exchange of Information as 'speculative requests for information that have no apparent nexus to an open inquiry or investigation'. Thus, that same information provided automatically by the source country about income accrued to residents in other jurisdictions is to be denied if requested as it would constitute a fishing expedition.

The difficulty raised by DAC 1 is more related to the fact that foreseeable relevance is included in Article 1 under 'General Provisions', Chapter 1:

Subject matter

1. This Directive lays down the rules and procedures under which the Member States shall cooperate with each other with a view to exchanging information that is foreseeably relevant to the administration and enforcement of the domestic laws of the Member States concerning the taxes referred to in Article

2. This Directive also lays down provisions for the exchange of information referred to in paragraph 1 by electronic means, as well as rules and procedures under which the Member States and the Commission are to cooperate on matters concerning coordination and evaluation.

Foreseeable relevance could be interpreted as a condition for implementing any modality of exchange of information. That would lead to an absurd outcome and, therefore, such interpretation is to refuse in light of the systematic and purposive elements of interpretation.

The inclusion of 'foreseeable relevance' in Article 1 of DAC instead brought more uncertainty about its effectiveness in protecting taxpayers' rights, and it appeared to be more of an empty principle as if it were an affirmation of goodwill included in the foreword of the directive.
Article 5a, paragraph 1, of the proposal for DAC 7 now attempts to clarify that foreseeable relevance is a concept linked to exchange of information upon request. This provision defines foreseeable relevance as the reasonable possibility that the requested information be relevant to the tax affairs of one or several taxpayers, whether identified by name or otherwise, and be justified for the purposes of investigation'.

It is not, in fact, an EU definition that is different from the international legal concept, and it has the merits of bringing together the elements that are scattered in the above mentioned several international instruments.

Simply stated, foreseeable relevance is a vague concept. The 'reasonable possibility that it is relevant' is another vague construct. It reinforces the idea of a previous judgment vis-à-vis the relevance of the outcome. A previous judgment cannot guarantee that the information will be relevant. This adheres to the international instruments approach and case law on the topic.

According to Article 5a, paragraph 1, the reasonable possibility that the information is relevant' is to be judged by the requesting state in accordance with its national law. This is also consistent with international tax law, specifically, with the old Powell criteria, based on the presumption that the requesting state acts in good faith. ${ }^{14}$

Moreover, requiring that the requesting state provides the 'supporting information' to demonstrate the foreseeable relevance (paragraph 2) is in line with Article 5 (5) of the Model Agreement on Exchange of Information which further specifies the type of information that a requesting party should provide to 'demonstrate the foreseeable relevance of the [requested] information to the request':

1. the identity of the person under examination or investigation;

2. a statement of the information sought including its nature and the form in which the applicant Party wishes to receive the information from the requested Party;

3. the tax purpose for which the information is sought;

4. grounds for believing that the information requested is held in the requested Party or is in the possession or control of a person within the jurisdiction of the requested Party;

5. to the extent known, the name and address of any person believed to be in possession of the requested information;

6. a statement that the request is in conformity with the law and administrative practices of the applicant Party, that if the requested information was within the jurisdiction of the applicant Party then the competent authority of the applicant Party would be able to obtain

\section{Notes}

13 A. P. Dourado, International Tax Transparency and Lost Meaning of Foreseeable Relevance, in CEF Tax Advisers Europe - 60th anniversary Liber Amicorum 249-251, at 241 et seq. (S. van Thiel, P. Valente \& S. Raventós-Calvo eds, IBFD 2019).

14 See US: Supreme Court 23 Nov. 1964, United States v. Powell., 379 US 48 (1964). 
the information under the laws of the applicant Party or in the normal course of administrative practice and that it is in conformity with this Agreement;

7. a statement that the applicant Party has pursued all means available in its own territory to obtain the information, except those that would give rise to disproportionate difficulties.

\section{Group ReQUeSTS UNDER DAC 7}

As mentioned above, foreseeable relevance is a concept requiring identification of the taxpayers involved in a specific affair. In turn, Article 5b of the Proposal for a DAC 7 explicitly provides for group requests when individual identification of the taxpayers is not required and covers tax evasion promoters:

"a group of taxpayers who cannot be identified individually by name or otherwise but can only be described on the basis of a common set of characteristics. The requesting competent authority shall provide: a) a comprehensive description of the common characteristics of the group; and b) an explanation of the applicable law and of the facts based on which there is reason to believe that the taxpayers in the group have not complied with the applicable law, including facts and circumstances related to the involvement of a third party that actively contributed to the potential non-compliance of the taxpayers in the group with the law."

This provision partially coincides but goes beyond the OECD conditions for group requests. In fact, Commentaries 5.2., 6, and 8 of the OECD MC require identification of each individual in the group and make no reference to the involvement of third parties:

An investigation into a particular group of taxpayers will serve 'the administration or enforcement' of its domestic tax laws and thus comply with the requirements of paragraph 1 , provided it meets the standard of 'foreseeable relevance'. However, "there will be a fishing expedition where the request relates to a group of taxpayers not individually identified; the requesting State cannot point to an ongoing investigation into the affairs of that particular group or provide a detailed description of the group; and the specific facts and circumstances that have led to the request; and other detailed explanation such as the applicable law; why there is reason to believe that the taxpayers in the group for whom information is requested have been non-compliant with that law supported by a clear factual basis; and that the requested information would assist in determining compliance by the taxpayers in the group.

\section{Data breach}

Article 25(5) DAC7 enables the Member States to ask the Commission to suspend exchanges of information with the Member State(s) when a data breach occurs (in the context of those exchanges). The Commission shall restore the process for the exchanges of information after the competent authorities ask it to again enable the exchanges of information under this Directive with the Member State where the breach occurred.

Although this consequence fills a gap in the current regime in international tax law, it is insufficient from the perspective of taxpayers' rights. It is dependent upon a Member State's request for suspension and does not provide for liabilities related to damages.

\section{Concluding Remarks}

It could be accepted that a definition of foreseeable relevance would bring increased legal certainty to tax authorities and might enhance the exchange of information upon request in the European Union. Nevertheless, it is questionable whether it is worth introducing a definition of foreseeable relevance in the DAC. Being a vague concept related to (dependent upon) the international concept and standard, there would be advantages in not defining it and leaving it flexible so that it could accompany any evolution in the international standard. It can be argued that the definition in Article 5a is vague and, therefore, capable of accommodating future developments. However, the question then is what the advantage is of introducing an additional vague concept in terms of legal certainty.

In turn, it can be concluded that 'group requests' in the EU, as proposed under DAC 7, will be a step forward in the exchange of information upon request as it extends beyond the OECD MC Commentaries.

Finally, Article 25(5) DAC 7 is insufficient in its current version from the perspective of taxpayers' rights as it is dependent upon a Member State's request for suspension and does not provide for liabilities. DAC 7 would be an advantageous opportunity to establish specific provisions on damages and liabilities: they should be focused on the taxpayers' rights and on whether both the information supplier and the information recipient or only one of them, is liable. Most importantly, those provisions should be binding and independent from the Member States' reactions.

$$
\begin{array}{r}
\text { Ana Paula Dourado } \\
\text { Editor-in-Chief } \\
\text { Email:anadourado@fd.ulisboa.pt }
\end{array}
$$

